\title{
Impairment Charges and Market Value of Insurance Firms in Nigeria
}

\author{
Gospel J. Chukwu ${ }^{1} \&$ Godpower W. Obah ${ }^{2}$ \\ ${ }^{1}$ Department of Accountancy, Ken Saro Wiwa Polytechnic, Rivers State, Nigeria \\ ${ }^{2}$ Department of Accountancy, Ignatius Ajuru University of Education, Port Harcourt, Nigeria \\ Correspondence: Gospel J. Chukwu, Department of Accountancy, Ken Saro Wiwa Polytechnic, Rivers State, \\ Nigeria. Email: gospeljchukwu@gmail.com
}

Received: January 3, 2019
doi:10.5539/ijbm.v14n4p171

Accepted: February 28, 2019 Online Published: March 8, 2019

URL: https://doi.org/10.5539/ijbm.v14n4p171

\begin{abstract}
The purpose of this study is to examine whether impairment of financial assets affects the behaviour of equity investors in the insurance industry in Nigeria. Using a sample of 102 firm-year observations drawn from 17 insurance firms, and another sample of insurance firms whose shares traded at more than par value, the study investigated whether share prices are associated with insurance receivables and with other financial assets. Findings show that share prices are not significantly associated with insurance receivables, or with other financial assets. This is possibly because the shares of many insurance firms in Nigeria traded mostly at par value within the sample period-2012 to 2017. Empirical results further reveal that for the sample of firms whose shares traded at more than par value, there is a significant negative relationship between impairment charges of financial assets and market value, suggesting that investors negatively view impairment charges and regard them as evidence of decline in the economic value of organisational assets. Even with the sample of firms whose shares traded at more than par value, there is an insignificant relationship between insurance receivables and market value, suggesting that investors do not regard the impairment of trade receivables as sufficiently reliable to include them in their assessment of firm value. Regulators of the insurance industry must therefore emphasise confidence-boosting strategies such as the merger of weak insurance firms. This will create larger firms with greater capacity and better performance, as well as improve investors' perception of the insurance industry in Nigeria.
\end{abstract}

Keywords: trade receivables, financial assets, impairment, market value, value relevance

\section{Introduction}

The financial services sector is central to the effective performance of any economy because of its role in financial intermediation, investment financing, and provision of coverage over many types of risks. The quality of assets recognised by firms in this sector reveals their competitive potential, going concern status, as well as their ability to deliver services efficiently and attract investors (Ikwuetoghu, 2018). In 2016, the assets of a prominent bank in Nigeria (Skye Bank Plc) were reported to be heavily impaired (Egene, 2016); two years thereafter the bank failed. This suggests that investors and other market participants should give attention to asset impairment charges reported by firms.

The insurance industry is a key sub-sector of the financial services sector in Nigeria, given its assets base of approximately N1 trillion (Agabi, 2018). With an insurance penetration that is less than two percent, compared to South African's 16.99 percent and Namibia's 6.69 percent (Onuoha, 2017; Statistica, 2017), the insurance industry in Nigeria has a vast growth potential that should attract investors within and outside the country. The low insurance penetration in the country is partly blamed on the capacity of the firms in the industry to meet their obligations; especially in terms of prompt settlement of insurance claims (Otoijagha, 2018; Yusuf, 2017). To guard against sharp practices in the industry, insurance firms must comply with the provisions of the Insurance Act and with the guidelines issued by the National Insurance Commission (NAICOM) from time to time.

The Insurance Act 2003 (Section 50) provides that an insurance firm in Nigeria shall receive premium from a policyholder before a cover is provided for any insurable risk. Thus, from the standpoint of an insurance firm, the receipt of a premium is a vital precondition for a valid insurance contract. In other words, if a policyholder fails to pay premium, the insurance firm is mandated by the Act to refrain from offering any form of insurance 
cover. Based on these requirements, insurance firms adopt a no premium no cover policy, and premiums not received from brokers after a specified period are deemed to be impaired.

A number of studies have examined the impairment of long-live assets (Hong, Park, \& Smith, 2018; Zhang, Zhangfei, \& Kongtao, 2010), impairment of goodwill (Laghi, Mattei, \& di Marcantonio, 2013; Lapointes-Antunes, Cormier, \& Magnan, 2009; Liberatore \& Mazzi, 2010), and impairment of assets generally using aggregate impairment numbers (Vanza, Wells, \& Wright, 2018). However, studies on the relationship between impairment of financial assets and capital market variables are scanty. This study examines whether impairment charges for insurance receivables and other financial assets affect the market valuation of insurance firms in Nigeria. The study is significant as the recognition of huge impairment charges by a quoted bank in Nigeria became an indication of the eventual collapse of the bank (Egene, 2016). Since much research attention has not been given to examine how investors value the impairment of insurance receivables and financial assets, this study fills gap in literature.

The remainder of this paper proceeds as follows. The next section explains the concept of impairment and financial assets, and presents a review of related literature and hypotheses development. This is followed by the section on methodology which discusses the research design, population, sample, and the model used in the study. The results and relevant discussions are presented next, and the final section concludes the paper.

\section{Literature Review}

\subsection{Impairment}

The carrying amount of the assets deployed in the production of goods and services is expected to be lower or at least equal to the recoverable amount, unless the economic value of the asset has diminished. When the carrying value of an asset exceeds its recoverable amount, the asset is impaired; and the extent of impairment is the amount by which the carrying value of the asset exceeds its recoverable amount. This is the view of International Accounting Standards (IAS) number 36, which requires that under such circumstances the reporting entity must reduce the carrying amount to the recoverable amount. The standard, however, addresses the impairment of non-current assets such as goodwill, property, plant and equipment, and other intangible assets. The objective of IAS 36 is to ensure that reporting entities complying with the requirements of International Financial Reporting Standards (IFRS) do not carry long-lived assets at a value greater than the recoverable amount.

The impairment of financial assets is one of the subjects currently addressed by IFRS 9 which became effective from 1 January 2018. This standard requires an entity to recognise an impairment loss allowance for financial assets based on expected credit losses on the assets. This provision applies to trade receivables and financial assets measured at amortised cost and at fair value.

In the sample period of this study, insurance companies in Nigeria applied the requirements of IAS 39 in the measurement and recognition of impairment loss. IAS 39 requires an entity to determine impairment loss based on incurred credit losses. A reporting entity is required to conduct an assessment of its financial assets at the end of each accounting year to determine whether there is objective evidence that the financial asset is impaired. If there is such evidence, the entity is required to determine the amount of impairment loss by computing the difference between the carrying value of the asset and present value of the asset's estimated future cash flows. The discount rate used in determining the present value is the original effective interest rate of the financial asset. The carrying amount of the financial asset is reduced by creating an allowance account, and the impairment loss is recognised in the entity's profit or loss. This rule is applicable to financial assets recognised in the statement of financial position at amortised costs.

For the insurance firms in this study, an objective evidence of impairment loss of a financial asset includes observable data arising from the following loss events:

a) Trade receivables (insurance receivables) are outstanding for more than 30 days.

b) Reinsurance recoverable is overdue for more than 30 days.

c) The issuer or debtor is experiencing significant financial difficulty.

d) There is default (or delinquency) in payment of principal or interest.

e) There is probability that the borrower may become bankrupt.

f) As a result of financial difficulty, an active market for the financial asset has disappeared (AXA Mansard, 2017).

\subsection{Trade Receivables and Financial Assets}

Trade receivables (also known as insurance receivables) are financial assets in the category of loans and 
receivables. These financial assets are non-derivative, have specified determinable payment, and are not quoted in any active market (AXA Mansard, 2017). On initial recognition, trade receivables are measured at fair value, but thereafter amortised cost is used as a basis of measurement (Consolidated Hallmark, 2017). The trade receivables of insurance firms in Nigeria consist of premium receivables from agents, brokers and direct clients.

Insurance firms adopt the policy of 'no premium, no cover' in consonance with section 50 of the Insurance Act 2003. This section requires that premium must be paid in advance for valid insurance contract to exist, and where premiums are not so paid, there shall be no cover. Given this policy, all insurance premiums are paid in advance except for transactions with brokers which are allowed for 30 days where the brokers have issued credit notes to the insurance firms. Trade receivables after 30 days are deemed to be impaired. Receivables are further tested for impairment using internal models developed by management in accordance with IAS 39 (AXA Mansard, 2017; Consolidated Hallmark, 2017).

Under IAS 32, financial assets are resources such as cash, investment in equity instrument issued by another entity, and a contractual right that entitles an entity to receive cash and other financial assets from another entity. Major classes of financial assets include available for sale financial investments, financial assets held for trading, as well as loans and receivables. Although trade receivables are part of loans and receivables, they are treated as a separate indicator variable in this study because they constitute a major source of revenue for insurance businesses. Other assets included in the definition of financial assets in this study are investment securities, loans to staff, finance lease receivable, bond investment, cash and cash equivalents, loans to policyholders, and mortgage loans.

\subsection{Empirical Review}

IAS 36 specifies a number of indicators of impairments that may be derived from external sources (such as decline in the value of asset) and internal sources (such as internal report showing that an asset's economic performance will decline). The association between these indicators and reported impairments losses in Thailand was tested using data from a sample of 1,418 listed non-financial firms for six years (1999-2004). Findings of the study shows that impairment losses are associated with indicators of impairment, and managers in these firms manage impairment losses opportunistically in order to smooth earnings (Peetathawatchai and Acaranupong, 2013).

Information on impairment loss allowance may not be useful to equity investors for decision making because impairment tests are sometimes not conducted with adequate rigor to result in faithfully represented numbers (Hoogervorst, 2012). Also, the recognition of impairment losses may be delayed or even manipulated by management to signal desired level of corporate performance (Francis, Hanna, \& Vincent, 1996; Gu \& Lev, 2011; Zang, 2008). These circumstances are possible because managers exercise some level of discretion in the determination of impairment losses (Axa Mansard, 2017; Vanza et al., 2018).

A number of studies on asset impairment focus on the impairment of goodwill arising from business combinations (AbuGhazelah, Al Hares, \& Haddad, 2012; Beatty \& Weber, 2006; Lapointe-Antunes et al., 2009; Li, Shroff, Venkataraman, \& Zhang, 2011; Ramanna \& Watts, 2011; Xu, Anandarajan, \& Curtola, 2011). Some of these studies examine whether equity investors value the impairment of goodwill arising from business combinations. The results from the studies provide mixed evidence on how the market values the impairment of purchased goodwill. For instance, AbuGhazelah et al. (2011), Bens, Heltzer and Segal, (2011), LapointeAntunes et al. (2009) and Xu et al. (2011) find that goodwill impairment is negatively and significantly related to stock market prices, suggesting that investors perceive impairments as reduction in the economic value of assets. However, Laghi et al (2013) report that the value relevance of goodwill impairment is country-dependent, while Liberatore \& Mazzi (2010) fail to find any relationship between goodwill impairment announcement and price volatility.

The discretion in the use of fair value estimates to determine asset impairments charges could be exploited by managers to convey private information about future cash flows. Alternatively, managers could use the estimates opportunistically in accordance with agency theory. Research evidence, however, suggests that manager use their discretion in fair value estimates opportunistically in conformity with agency theory (Ramanna \& Watts, 2008). An earlier study had examined the managerial incentives to record current goodwill impairment charges immediately below-the-line or to delay expense recognition above-the-line. This choice is affected by several factors including the desire to influence equity investors, debt contracting arrangements, turnover, bonus and fear of possible delisting from the stock exchange (Beatty \& Weber, 2006). Evidence from listed Italian firms supports the assertion that several incentives motivate management discretion in determining goodwill impairment charges (Korosec, Jerman, \& Torminc, 2016). 
The migration from incurred loss impairment model to expected credit loss impairment model has led to the search for a model to predict expected credit losses. The new impairment model applies to different types of receivables including lease receivables and trade receivables. One approach in developing the model is to examine how the IAS 39 impairment model can be modified to meet the requirements of the expected credit loss impairment model required by IFRS 9. Several models have been suggested, including the use of binomial model in determining the expected credit losses from various accounts receivables including related party loan receivables (Ramenaric, Cevizovic, \& Kenfalja, 2018). The European Financial Reporting Advisory Group (2018) also examine the problem associated with the implementation of the impairment model in IAS 39 and illustrate two models, the impairment model and revaluation model, but fail to recommend any of options as the preferred model. Many of the firms that responded to the study were concerned about how the application of IFRS 9 will affect their asset allocation decisions. Interestingly, insurance firms are allowed up to 2021(when IFRS 17 will become effective) to fully implement IFRS 9.

How impairments charges affect earning depends largely on the accounting requirements applied. Firms using one suite of accounting standards could record higher or lower earnings impact than firms using another set of accounting standards. Hong et al. (2018) examine this problem using data from US firms adopting US GAAP and those adopting the impairment loss requirements of IFRSs. Findings of the study show that the association between impairment loss and earnings is significantly greater for firms adopting the US GAAP than for firms using the requirements of IFRSs. Relatedly, Zhang et al. (2010) examine how a change in accounting requirements on impairment loss recognition affects earning numbers, based on data from Chinese listed firms. In 2005, accounting regulators in China issued a new accounting requirement prohibiting the reversal of impairments on long-lived assets with effect from 2017. Results from contrasting impairment loss recognition and impairment loss reversals in the period before the new rule and the period after, indicate that Chinese listed firms recognised less impairment losses in the period between the announcement of the new requirement and its implementation, than in the period before the transition. Also some of the firms with relatively high amount of impairment charges reversed these charges to achieve desired earnings target in the period of the transition. This evidence suggests that impairment charges and impairment loss reversals can be used to manage earnings (Hong et al., 2018). Evidence from listed firms in Australia, however, suggests that impairment charges are associated with reduction in information asymmetry especially during the period of financial crises (Vanza et al., 2018).

Sanmo, Ginesti and Drago (2015) examine the factors that affect decisions on quantitative thresholds for impairment indicators, using data from Italian banks for two years (2010-2011). The study was motivated by the sparse literature on impairment for available for sale financial assets. Findings indicate that the choice of whether or not to reclassify financial assets following the amendments to IAS 39, as well as the need for profitability, determined the quantitative thresholds used by banks to assess the impairment of available for sale equity instruments.

The foregoing review shows that there are a number of studies on impairment of goodwill, other intangibles, long-lived assets, and assets generally. But impairment of financial assets and insurance receivables has not received much research attention; therefore, this study fills gap in literature.

\subsection{Hypotheses Development}

Poor reputation of insurance firms in Nigeria arising from claims settlement default and perceptions of lack of transparency in insurance practice may have contributed to the general apathy to insurance in Nigeria, resulting in low insurance penetration and depressed investors' interest in the stocks of insurance firms (Onuoha, 2017). Given this setting, it is reasonable to expect that accounting numbers such as impairment of trade receivables and impairment of financial assets may not be of any significant interest to investors in the insurance industry. Therefore, the first two hypotheses of this study are as follows:

\section{H1 Impairment charges on insurance receivables do not affect equity investors' valuation of insurance firms}

\section{H2 Accounting information on impairment charges of financial assets is not value relevant.}

One of the consequences of investors' apathy towards insurance firms is that the shares of some of the firms trade from time to time at par value. This poor performance of insurance firms is attributable to the low returns received by investors in that sub-sector. For instance, in 2016, only six insurance firms declared and paid dividends to their shareholders (Bello, 2017). The share prices of a handful of insurance companies, however, trade at more than par value. This situation gives rise to two categories of firms in the insurance sub-sector firms whose share prices hardly trade above par value and those whose shares trade mostly above par value. The firms in the latter category may have value relevant accounting information. Prior studies have shown that investors value impairment charges negatively possibly because of their adverse effect on firm performance (Xu 
et al., 2011; Lapointe-Antunes et al., 2009; Bens et al., 2011). Accordingly, the next two hypotheses are as follows:

H3 Impairment charges on trade receivables are negatively related to the market value of insurance firms whose shares trade mostly at more than par value.

H4 Impairment charges on financial assets are negatively valued by investors in insurance firms whose shares trade at more than par value.

\section{Methodology}

\subsection{Research Design}

As noted above, the stock of some insurance firms trade almost continuously at par value, while that of a few firms in the industry trade at varying prices higher than the par value. To address the first two hypotheses, the study evaluated the effect of impairment charges on market value of firms in the industry, irrespective of whether or not the shares traded at par value. To address the remaining hypotheses, the study analysed how impairment charges are associated with the share prices of firms whose shares traded at more than par value for at least half of the sample period. Share prices used are six months after year end so that information on impairment charges will be available to market participants.

This study used correlational research design based on the Ohlson (1995) model. The Ohlson model proposes that stock prices impound information provided by financial statements. The model relates stock prices to book value, earnings and other accounting information. Since this study examines the association between impairment charges and market value, the Ohlson model is considered appropriate for the study. In applying the model, the study included earnings per share and book value of equity per share as control variables; book value and earnings are key variables identified in the model as capable of affecting market value. Since prior studies have also shown that a significant relationship subsists between firm size and the stock returns of financial firms (Barber \& Lyon, 1997), this study also included firm size as a control variable. Firm size is regarded in this study as part of other information that could affect the market value of insurance firms. The Ohlson (1995) model recognises that other variables (besides book value, earnings and dividend) affect stock prices.

Therefore, to determine the effect of trade receivables' impairment, and financial assets impairment, on the market value of insurance firms, this study used the following model:

$$
\mathrm{SP}_{\mathrm{i}}=\mathrm{a}_{0}+\mathrm{a}_{1} \mathrm{IMTRi}+\mathrm{a}_{2} \mathrm{IMFAi}+\mathrm{a}_{3} \text { EPSi }+\mathrm{a}_{4} \text { BVPSi }+\mathrm{a}_{5} \mathrm{FSi}+\mathrm{e}_{\mathrm{i}}
$$

\section{Where}

$\mathrm{SP}=$ Share price six months after year end.

IMTR $=$ impairment charges on trade receivables

IMFA $=$ impairment charges on other financial assets

EPS $=$ earnings per share

BVPS = book value of equity per share

$\mathrm{FS}=$ firm size (natural logarithm of total assets)

\subsection{Population and Sample}

There are 26 quoted insurance firms listed under the financial services sector in the 2017/2018 FACT BOOK of the Nigerian Stock Exchange (NSE, 2018). Financial Statements summary up to the year ended $31^{\text {st }}$ December 2017 was available for only 17 companies, suggesting that the annual reports of some insurance firms had not been approved at the time the current FACT BOOK was published. Delay in approval of annual financial statements may be due to late submission of reports by the reporting entity or irregularity in financial reporting observed by the approving authority. Using the census process of sample selection, the study selected all the 17 companies in the sampling frame to constitute the first sample. The period of the study is 2012 to 2017. The choice of 2012 (the year Nigeria adopted IFRSs) is to ensure that the requirements of IAS 39 in relation to impairment of financial assets will be applicable to all firms in the industry. Given the study period of six years, the expected number of firm-year observations is 102 .

The second sample is drawn from firms whose shares traded at more than par value for at least half of the period covered by the study. Only 7 insurance firms met this requirement. These firms therefore constitute the second sample. Given the study period of six years, the expected number of firm-year observations for the second sample is 42 . 


\section{Results and Discussion}

\subsection{Descriptive Statistics}

Table 1 presents the descriptive analyses of the variables used in the study. Share prices range from 50 kobo to $\mathrm{N} 2.96$, with a mean price of 68 kobo, suggesting that the average share price in the industry is slightly higher than $50 \mathrm{kobo}$, the par value of shares in the industry. The implication is that the industry may not be attractive to investors, possibly due to poor investors' perception of the industry, as well as general lack of awareness of the benefits of risk coverage in the economy.

Table 1. Descriptive statistics

\begin{tabular}{llllllll}
\hline & N & Range & Minimum & Maximum & Sum & Mean & Std. Dev. \\
\hline SP & 102 & 2.46 & 0.5 & 2.96 & 70.27 & 0.6889 & 0.45364 \\
IMTR & 102 & 2805 & 0 & 2805 & 18201.9 & 178.45 & 436.95436 \\
IMFA & 102 & 1270 & 0 & 1270 & 6059.32 & 59.4051 & 182.42191 \\
EPS & 102 & 186 & -39 & 147 & 803.61 & 7.8785 & 18.5899 \\
BVPS & 102 & 2.29 & 0 & 2.49 & 108.80 & 1.0667 & 0.56754 \\
FS & 102 & 3.15 & 8.28 & 11.43 & 967.13 & 9.4816 & 0.71115 \\
\hline
\end{tabular}

Source of data is the annual report of selected firms.

The maximum amount for impairment of trade receivables is N2.8bn, suggesting that a firm in the sample recognised impairment charges on trade receivables of nearly N3bn in one of the years within the sample period. The mean of impairment charges for trade receivables is greater than that of financial assets although in the statement of financial position of insurance firms the carrying value of financial asset is higher than that of trade receivables (see Consolidated Hallmark, 2017; Prestige Assurance, 2017). The lower amount of impairment of financial assets relative to that of trade receivables may be due to the fact that the measurement of financial asset impairment allows for greater managerial discretion than the determination of impairment of insurance receivables. Under the Insurance Act 2003, premium not received at the end of the period is deemed to be impaired, and any premium receivable through brokers is deemed impaired if it is outstanding for more than 30 days. In many cases, impairment of trade receivables recognised in one period is reversed in the succeeding period.

Table 2. Correlations

\begin{tabular}{lllllll}
\hline & SP & IMTR & IMFA & EPS & BVPS & FS \\
\hline SP & 1 & -0.041 & -0.015 & $.252^{* *}$ & $.427^{* * *}$ & $.599^{* * *}$ \\
IMTR & -0.041 & 1 & $.289^{* * *}$ & -0.178 & -0.082 & -0.019 \\
IMFA & -0.015 & $.289 * * *$ & 1 & -0.176 & -0.064 & 0.125 \\
EPS & $.252^{* *}$ & $-0.178^{*}$ & $-0.176^{*}$ & 1 & $.332^{* * *}$ & $.458^{* * *}$ \\
BVPS & $.427 * * *$ & -0.082 & -0.064 & $.332^{* * *}$ & 1 & $.571^{* * *}$ \\
FS & $.599^{* * *}$ & -0.019 & 0.125 & $.458^{* * *}$ & $.571^{* * *}$ & 1 \\
\hline
\end{tabular}

* Correlation is significant at the 0.10 level; ** at the 0.05 level; *** at the 0.01 level

The mean of earnings per share is $7.87 \mathrm{k}$, while the mean of book value of equity per share is N1.08. These figures compare unfavourably with those of firms in other industries. For instance, the mean of earnings per share from a sample of Nigerian banks based on data from 2012 to 2016 was $160.8 \mathrm{k}$ (Chukwu \& Salifu, 2018), and the mean of book value of equity per share of listed Breweries from 2008 to 2017 was N10.5 (Chukwu \& Wadike, 2018). Given the numbers in other industries, insurance firms in Nigeria are not among the top profitable industries in the country. The depressed profitability in the industry explains why only six firms could pay dividends in 2016 (Bello, 2017).

\subsection{Bivariate Correlation of Variables}

Table 2 presents the bivariate correlations of the variables in the study based on data from the first sample. The highest correlation among the variables is about 60 percent, suggesting that the issue of multi-collinearity may not be a problem in this study. The correlation between share price (SP) and impairment of trade receivables 
(IMTR) is negative and insignificant, and the correlation between share price (SP) and impairment of financial assets (IMFA) is similarly insignificant, suggesting that neither impairment of trade receivables nor impairment of financial assets has significant effect on market value in the insurance industry.

The correlation between the impairment of trade receivables and financial asset impairment is positive and significant. This is understandable because the both measures are guided by the requirements of IAS 39 . Similarly, the correlation between earnings per share and book value of equity per share is positive and significant, possibly because earnings enhance the value of shareholders equity. In the clean surplus relation earnings is an important determinant of changes in book value.

Table 2 also shows that firm size is positively and significantly related to share price, earnings per share and book value per share, but not to impairment of trade receivables or impairment of financial assets. These relationships suggest that impairment of trade receivables and financial assets impairment are not affected by the size of the insurance firm. On the other hand, firm size affects share price, earnings per share and book value of equity per share in the insurance industry.

\subsection{Multivariate Analysis}

Table 3 presents the result of regression of impairment of trade receivables and impairment of financial assets on market value based on data from the first sample. Impairment of trade receivables (IMTR) is negatively associated with share price (SP), suggesting that investors view impairments as reduction in the economic value of assets, but the relationship is not significant. Similarly, impairment of financial assets (IMFA) is negatively and insignificantly associated with market value, suggesting that investors are not impressed by impairment numbers reported by insurance firms. Similarly, earnings per share and book value of equity per share are insignificantly related to share price, suggesting that investors in the industry do not also consider these accounting measures useful for equity valuation. The lack of profitability and consequent none payment of dividends may have accounted for the apparent investors' apathy towards the industry. This situation had discouraged retail investors in the industry and constrained them to look elsewhere, especially since after the financial melt-down of 2009 (Bello, 2017).

Table 3. Results of regression analysis (first sample)

\begin{tabular}{llllllll}
\hline & \multicolumn{3}{c}{ Robust } & & & \multicolumn{2}{l}{} \\
Variables & Coeff & Std error & $\mathrm{T}$ & $\mathrm{P}>|\mathrm{t}|$ & \multicolumn{2}{l}{ VIF } & \multicolumn{2}{l}{ Model Summary } \\
\hline IMTR & $-6.59 \mathrm{e}-06$ & .0000451 & -0.15 & 0.884 & 1.11 & No. of obs & 102 \\
IMFA & -.0002227 & .0001646 & -1.35 & 0.179 & 1.19 & $\mathrm{~F}(5,96)$ & 4.66 \\
EPS & -.0016166 & .0025709 & -0.63 & 0.531 & 1.38 & Prob $>$ F & 0.000 \\
BVPS & .0914215 & .060636 & 1.51 & 0.135 & 1.53 & R-squared & 0.378 \\
FS & .3670836 & .1091016 & 3.36 & 0.001 & 1.83 & Adj R-sqd & 0.346 \\
Cons & -2.862007 & .9795456 & -2.92 & 0.004 & & Root MSE & 0.366 \\
\hline
\end{tabular}

Source: Authors' computations

The Ohlson (1995) model relates share price to earnings and book value, and several studies have found these numbers value relevant (Chukwu, Ohaka \& Nwayanwu, 2017; Chukwu \& Okoye, 2014). An earlier study on the effect of IFRS adjustments on market value in the insurance industry failed to document any significant effect of accounting amounts on the share prices of firms in the insurance industry (Chukwu, 2017). The lack of value relevance of summary accounting amounts in the insurance industry in Nigeria is because the shares of a number of firms in the industry trade mostly at par value.

Table 4 presents the results of a sample of seven insurance firms whose shares traded at more than par value (for at least half of the sample period). Impairment of trade receivables is negatively associated with share prices but the relationship is not significant. The coefficient for impairment of financial assets is negative and the $t$ statistic is significant at the 10 percent level, suggesting that impairment of financial assets is significantly and negatively associated with market value. This finding is consistent with related studies that examine the market valuation of goodwill impairment. Findings of these studies indicate a significant negative relationship between goodwill impairment and market value, suggesting that investors have negative perception of goodwill impairment charges as they view these charges as reduction in the value of goodwill asset (AbuGhazaleh et al., 2012; Lapointe-Antunes et al., 2009; Xu et al., 2011). Accordingly, it is possible that investors in the insurance industry perceive financial assets impairment as reduction in the value of organisational asset, and therefore negatively 
value this accounting amount. Thus, the more impairment charges a firm recognises, the more negatively investors are likely to value the firm.

The other independent variables in the study are control variables. Earnings per share (EPS) is insignificantly related to share prices, suggesting that earnings numbers are not value relevant in the insurance industry. Book value of equity per share (BVPS) is negatively associated with share prices, and the relationship is significant at the 5 percent level. The significant negative relationship between book value of equity per share and share prices suggests that insurance firms with greater market capitalisation rely more on debt financing than equity financing. This is possibly because of investors' apathy which continues to trail stocks in the insurance industry (Bello, 2017).

Table 4. Results of regression analysis (second sample)

\begin{tabular}{llllllll}
\hline Variables & Coeff & Robust Std error & $\mathrm{t}$ & $\mathrm{P}>|\mathrm{t}|$ & $\mathrm{VIF}$ & Model Summary \\
\hline IMTR & -.0000396 & .0001114 & -0.36 & 0.724 & 1.38 & No. of obs & 42 \\
IMFA & -.0006306 & .0003457 & -1.82 & 0.076 & 1.41 & $\mathrm{~F}(5,36)$ & 2.14 \\
EPS & -.0048137 & .0031712 & -1.52 & 0.138 & 1.28 & Prob $>$ F & 0.083 \\
BVPS & -.0026323 & .0010119 & -2.60 & 0.013 & 1.02 & R-squared & 0.343 \\
FS & .5156167 & .1736134 & 2.97 & 0.005 & 1.32 & Adj R-sqd & 0.252 \\
Cons & -4.037226 & 1.597953 & -2.53 & 0.016 & & Root MSE & 0.534 \\
\hline
\end{tabular}

Source: Authors' computations.

The final control variable in the study is firm size. Results in Table 4 show that firm size is significantly and positively associated with market value at the 1 percent level, suggesting that the few firms whose shares traded at more than par value are also among the largest firms. Larger firms generally have greater debt capacity. The ability to pay debts (such as claims in the case of insurance firms) is very important and such capacity affects the reputation of insurance firms and may consequently affect their valuation.

Results of the study support hypothesis 1 which proposes that impairment of trade receivables does not affect the behaviour of equity investors in the insurance industry. The results also support hypothesis 4 which proposes that the impairment of financial assets of firms whose shares trade at more than par value is negatively valued by investors. The other hypotheses are not supported by the results of the study.

\subsection{Regression Diagnostics}

To address autocorrelation and possible heteroskedasticity, this study used robust standard errors as shown in Tables 3 and 4. The study used variance inflation factor to measure multi-collinearity. A variance inflation factor (VIF) which is greater than 10 is often regarded as indicative of serious multi-collinearity (Marquardt, 1970). From Tables 3 and 4, the VIFs in this study are far below 5, suggesting that instability of parameter estimates which may result from the problem of multi-collinearity is not an issue in this study. The adjusted R squared numbers in the two tables are reasonable and the $\mathrm{F}$ values are significant, suggesting that the models fit the data.

\section{Conclusion}

Impairment charges for financial assets are value relevant for investors in insurance firms whose shares trade at more than par value. These investors possibly view impairment charges as evidence of decline in the economic value of firm resources; and therefore, they negatively value this accounting amount. The impairment charges of insurance receivables, however, are not significantly associated with the market value of insurance firms, possibly because investors lack confidence in insurance practice in the country. Thus, investors in the insurance industry do not consider impairment of insurance receivables as relevant information for equity valuation. Accordingly, regulators of the insurance industry must devise strategies that will improve public perception of insurance firms as well as raise investors' confidence in their financial reporting and other practices. Since firm size was significantly associated with market value in both samples, strategies such as merger of weak insurance firms may be useful in improving financial performance and investors' confidence.

As with many other studies, the current study has its limitations. First, generalizability of the findings of the study is limited because one of the key variables in the research is impairment of insurance receivable, a variable that is only relevant to insurance businesses. Thus, some findings of this study may not be applicable to firms in other industries. Second, the study used data from quoted insurance firms only. In Nigeria, there are a number of unquoted insurance firms that are registered with the National Insurance Commission. For these insurance firms, 
the findings of this study may have limited applicability as their shares are not publicly valued. Last, a number of insurance firms in Nigeria trade mostly at par value. Thus, the findings of the study may have limited generalizability in economies with more price-sensitive insurance shares. Fortunately, the Nigerian Stock Exchange has introduced new Par Value Rules and Share Pricing Methodologies that allow low-priced shares to trade at less than par value. How this new rule will affect the market valuation of impairment of financial assets in Nigeria is a matter for future studies.

\section{References}

AbuGhazaleh, N. M., Al-Hares, O. M., \& Haddad, A. E. (2012). The value relevance of goodwill impairments: UK evidence. International Journal of Economics and Finance, 4(4), 206-216. https://doi.org/10.5539/ijef.v4n4p206

Agabi, C. (2018, March 26). Insurance still too small to cover Nigeria's risk. Daily Trust. Retrieved from https:// www.pressreader.com $>$ daily-trust

AXA Mansard. (2017). AXA Mansard Insurance Plc and Subsidiaries Annual Report for the year ended 31 December 2017. Retrieved from https://www.axamansardplc.com/documents/21505/40472/2017.AXA

Barber, B. M., \& Lyon, J. D. (1997). Firm size, book-to-market ratio, and security returns: A holdout sample of financial firms. The Journal of Finance, LII(2), 875-883. https://doi.org/10.2307/2329503

Beatty, A., \& Weber, J. (2006). Accounting discretion in fair value estimates: An examination of SFAS 142 goodwill impairments. Journal of Accounting Research, 44, 257-288. https://doi.org/10.1111/j.1475-679.2006.002.x

Bello, O. (2017, July 31) Investors apathy continue to trail insurance stocks. Leadership. Retrieved from https://leadership.ng.2017/07/31

Bens, D.A., Heltzer, W., \& Segal, B. (2011). The information content of goodwill impairments and SFAS 142. Journal of Accounting, 26(3), 527-555. https://doi.org/10.1177/0148558X11401551

Chukwu, A.N., Ohaka, J., \& Nwanaynwu, L. N. (2017). Intangible assets and market value of quoted deposit money banks in Nigeria. UNIPORT Journal of Business, Accounting \& Finance Management, 8(1), 184-199.

Chukwu, G. J. (2017). Market valuation of IFRS reconciliation adjustments in the insurance industry: Evidence from Nigeria. Journal of Global Accounting, 5(1), 224-231.

Chukwu, G. J., \& Okoye, I. E. (2014). The effect of mandatory IFRS adoption on earnings smoothing and value relevance of accounting information: Evidence from Ghana, Nigeria and South Africa. Paper presented at African Accounting and Finance Association (AAFA) $4^{\text {th }}$ Annual Conference at Cape Town, South Africa.

Chukwu, G. J., \& Salifu, D. (2018). Purchased goodwill and financial performance of banks in Nigeria, IOSR Journal of Business and Management, 20(10), 52-58. https://doi.org/10.9790//487X-2010025258

Chukwu, G. J., \& Wadike, G. C. (2018). Lease arrangements and financial performance of breweries in Nigeria. Research Journal of Accounting and Finance, 9(18), 86-93.

Consolidated Hallmark. (2017). 2017 Annual Report and Accounts. Retrieved from http://www.nse.com/.../21504_consolidated_hallmark.2017_afs_financial

European Financial Reporting Advisory Group. (2018). Equity investments - impairment and recycling. Retrieved from https://www.accountancyeurope.eu

Egene, G. (2016). Skye Bank incurs N40bn loss on N35bn impairment charges. Thisday. Retrieved from https://www.thisdaylive.com

Federal Republic of Nigeria. (2003). Insurance Act 2003. Lagos: The Federal Government Press

Federal Republic of Nigeria. (1997). National Insurance Commission Act 1997. Lagos: The Federal Government Press

Francis, J., Hanna, I., \& Vincent, J. (1996). Causes and effects of discretionary asset write-offs. Journal of Accounting Research, 34(1), 117-134. https://doi.org/10.2307/2491429

Gu, F., \& Lev, B. (2011). Overpriced shares, ill-advised acquisitions and goodwill impairment. The Accounting Review, 86(6), 1995-2022. https://doi.org/10.2308/accr.10131

Hong, P. K., Park, D. G., \& Smith, J. V. (2018). A study of long-lived asset impairment under US GAAP and 
IFRS within the US institutional environment. Journal of International Accounting, Auditing \& Taxation, 31, 74-89. https://doi.org/10.1016/j.intaccaudtax.2018.05.001

International Accounting Standards Board. (2018). International Accounting Standard 32 Financial Instruments Presentation. London: IFRS Foundation

International Accounting Standards Board. (2018). International Accounting Standard 36 Impairment of Assets. London: IFRS Foundation

International Accounting Standards Board. (2018). International Accounting Standard 39 Financial Instruments Recognition and Measurement. London: IFRS Foundation

International Accounting Standards Board. (2018). International Financial Reporting Standards 9 Financial Instruments. London: IFRS Foundation

Ikwuetoghu, C. (2018). Foreign investors uninterested in Nigeria's weak banks. Business Day. Retrieved from Businessday online.com

Korošec, B, Jerman, M., \& Tominc, P. (2016). The impairment test of goodwill: an empirical analysis of incentives for earnings management in Italian publicly traded companies Economic Research-Ekonomska Istraživanja, 29(1), 162-176. https://doi.org/10.1080/1331677X2016.1164923

Lapointe-Antunes, P., Cormier, D., \& Magnan, M. (2008). Equity recognition of mandatory accounting changes: The case of transitional goodwill impairment losses. Canadian Journal of Administrative Sciences, 25, 37-54. https://doi.org/10.1002/cjas.41

Laghi, E., Mattel, M., \& Marcantonie, M. (2013). Assessing the value relevance of goodwill impairment considering country-specific factors: Evidence from EU listed companies. International Journal of Economics and Finance, 5(7), 32-49. https://doi.org/10.5539/ijef.v5n7p32

Liberatore, G., \& Mazzi, F. (2010). Goodwill write off and financial market behaviour: An analysis of possible relationships. Advances in accounting, Incorporating Advances in International Accounting, 26(2), 333-339. https://doi.org/10.1016/j.adiac.2010.08.001

Li, Z., Shroff, P., Venkataraman, R., \& Zhang, I. X. (2011). Causes and consequences of goodwill impairment losses. Review of Accounting Studies, 16(4), 745-778. https://doi.org/10.1007/s11142.011-9167-2

Marquardt, D. W. (1970). Generalised inverses, ridge regression, biased linear estimation, and non-linear estimation. Technometrics, 12(3), 591-612. https://doi.org/10.2307/1267205

Nigerian Stock Exchange. (2018). NSE 2017/2018 Fact Book. Lagos: The Nigerian Stock Exchange

Ohlson, J. A. (1995). Earnings, book values and dividends in equity valuation. Contemporary Accounting Research, 11(2), 661-687.

Onuoha, R. (2017). Insurance penetration in Nigeria is still under 1.0\% - Ojumah. Vanguard. Retrieved from https://www.vanguardngr.com

Otoijagha, M. (2018). Claims refusal: Underwriters risk N30bn industry contribution to statutory deposit. Stock watch.

Peetathawatchai, P., \& Acaranupong, K. (2012). Are impairment indicators and losses associated in Thailand? Journal of Financial Reporting \& Accounting, 10, 95-114. https://doi.org/10.1108/19852511237462

Prestige Assurance (2017). Annual Report and Accounts 2017. Retrieved from http://www.nse.com.ng/.../Financial_NewsDocs/21497_PRES TIGE_ASSUR_DEC 2017

Ramanna, K., \& Watts, R. (2008). Evidence from goodwill non-impairments on the effects of using unverifiable $\begin{array}{lllll}\text { estimates in financial reporting. } & \text { Retrieved from }\end{array}$ http://www.hbs.edu.faculty/Publication\%20Files/08_014.pdf

Remenaric, R., Cevizovic, I., \& Kenfeija, I. (2018). Binomial model for measuring expected credit losses in trade receivables in non-financial sector entities. Preliminary Communication, 31(1), 125-135.

Statistica. (2017). Rate of insurance penetration in sub-Saharan African. Retrieved from http://www.statistica.com

Vanza, S and Wells, P., \& Wright A. (2018). Do asset impairments and the associated disclosures resolve uncertainty about future returns and reduce information asymmetry? Journal of contemporary Accounting and Economics, 14(1), 22-40. https://doi.org/10.1016/j.jcae.2018.02.003 
Xu, W., Anandarajan, A., \& Curatola, A. (2011). The value relevance of goodwill impairment. Research in Accounting Regulation, 23(2), 145-148. https://doi.org/10.1016/j.raereg.2011.06.007

Yusuf, I. A. (2017). Nigeria has lowest insurance penetration rate world-wide. The Nation. Retrieved from http://www.thenationonline.net

Zang, R., Zhengfei, L., \& Kangtao, Y. (2010). How do firms react to the prohibition of long-lived asset impairment reversals? Evidence from China. Journal of Accounting and Public Policy, 29(5), 424-438. https://doi.org/10.1016/j.jaccpubpol.2010.09.010

Zang, Y. (2008). Discretionary behavior with respect to the adoption of SFAS no. 142 and the behavior of security prices. Review of Accounting and Finance, 7, 38-68. https://doi.org/10.1108/14757700810853842

\section{Copyrights}

Copyright for this article is retained by the author(s), with first publication rights granted to the journal.

This is an open-access article distributed under the terms and conditions of the Creative Commons Attribution license (http://creativecommons.org/licenses/by/4.0/). 